\title{
Implementation of SMS Gateway as Informatioan System at SMKN 2 Kabupaten Sorong
}

\author{
Muhammad Ihsan ${ }^{1}$, Ismail Suardi Wekke ${ }^{2}$ Leo Pratama ${ }^{3}$, Musyrifah ${ }^{4}$ \\ Universitas Pendidikan Muhammadiyah Sorong, Institut Agama Islam (IAIN) Sorong, \\ Universitas Pendidikan Muhammadiyah Sorong, Universitas Sulawesi Barat \\ muhammadihsanunimudasorong@gmail.com, iswekke@gmqil.com, \\ leopratama12345@gmail.com, musyrifah65@gmail.com.
}

\begin{abstract}
The SMS gateway as an information system at SMK Negeri 2 Kabupaten Sorong can facilitate information delivery. Both the delivery of information for students and parents/guardians, as well as for school staff. This study aims to develop an information system with SMS Gateway at SMK Negeri 2 Kabupaten Sorong. The use of the SMS Gateway system is a solution for delivering school information. This research uses a research \& development (R\&D) approach. Data collection was done by using the observation method, literature study, and interviews. The output of this research is an SMS Gateway system that makes it easier for SMK Negeri 2 Kabupaten Sorong to deliver information to students, parents/guardians, and staff. The system test uses the White Box and Black Box methods with the results that the functions in the SMS Gateway system have functioned correctly and as expected.
\end{abstract}

Keyword : SMS Gateway, Information System

\section{Introduction}

Technology has accelerated development in various fields. Including in the field of software and hardware. Information technology has become an important part of our lives. All the conveniences offered by information technology, make it almost inseparable from our lives (Istri Sulistiyowati, 2012).

Before determining the information system to be used, it is necessary to consider environmental and community conditions. In the field of education, SMS-based services can be used as communication media between schools and parents that can help identify problems and monitor student progress at schools and help accelerate the education process (Istri Sulistiyowati, 2012).

SMK Negeri 2 Kabupaten Sorong is one of the State Vocational High Schools in Sorong Regency which is located at Katapo, Petrogas Street, far from the city center. The area where SMK Negeri 2 Kabupaten Sorong is located is a hilly area with inadequate internet access. Not to mention the condition of people who still lack knowledge about the internet. So that other alternatives are needed to deliver information. An alternative that can be used to overcome these problems is to use cellular technology combined with the SMS Gateway apps. In principle, an SMS gateway is software that utilizes computer and cellular technology to deliver messages through an information system using SMS.

The advantage of SMS gateway is that it is a computer-based application so that it can store large amounts of data because it is stored on the server hard disk (Sihotang, FP, \& Jumeilah, F. S: 2017). This is because most people do not have devices to access the internet, while almost all people already have mobile devices that can be sent and receive SMS. Also, the cellular network in the area is adequate for sending and receiving information. So that by using the SMS Gateway as an information system at SMKN 2 Kabupaten Sorong, the information delivery will be easier to do. 
From these problems, researchers need to develop an information system at SMKN 2 Kabupaten Sorong with the research title "Implementation of SMS Gateway as Information System at SMKN 2 Kabupaten Sorong". This system is expected to help the school to deliver information to students and parents.

\section{Theoretical Review}

\subsection{Information System}

A system is a form of integration between one component and another because the system has different goals for each case that occurs in the system (Sutabri, T. 15: 2012).

Information is data processed into a more useful form for those who receive it (Sihotang, $\mathrm{H}$. T.: 2018). An information system is a collection of interrelated elements that form a single unit to integrate data, process, and store, and distribute information (Sihotang, H. T.: 2018).

\subsection{SMS Gateway}

Short Message Service (SMS) can send and receive text messages to and from mobile phones. The text can consist of letters, numbers, or alphanumeric combinations (Afrina, M., \& Ibrahim, A: 2015). SMS gateway is a gateway for information dissemination using SMS. the process of disseminating or requesting a piece of information is done through a server. SMS gateway can customize keywords and what information to be sent (Suryana, T, 2012). SMS is called a text message because the message sent is only a text character that is not more than 160 characters long. Initially, SMS was designed as part of the GSM (Global Standard for Mobiles) network. But now it has expanded to other mobile networks, including TDMA (Time Division Multiple Access) and CDMA (Code Division Multiple Access).

\subsection{Gammu}

Gammu is an application that can be used to manage various functions on mobile phones, modems, and other similar devices (Masruri, M. H., \& Creativity, J.: 2015). Gammu is a liaison (gateway) that connects computer devices with cellphone or modem devices. In special cases, Gammu can be used as an SMS gateway (Sardiarinto: 2014).

\section{Research Method}

This research is a research and development (R\&D) using a 4D model developed by Sivasailam Thiagarajan, Dorothy S. Semmel, and Melvyn I. Semmel consisting of define, design, develop and disseminate (in Irma, 2013). The design of the SMS Gateway as an information system at SMKN 2 Kabupaten Sorong uses a prototyping model.

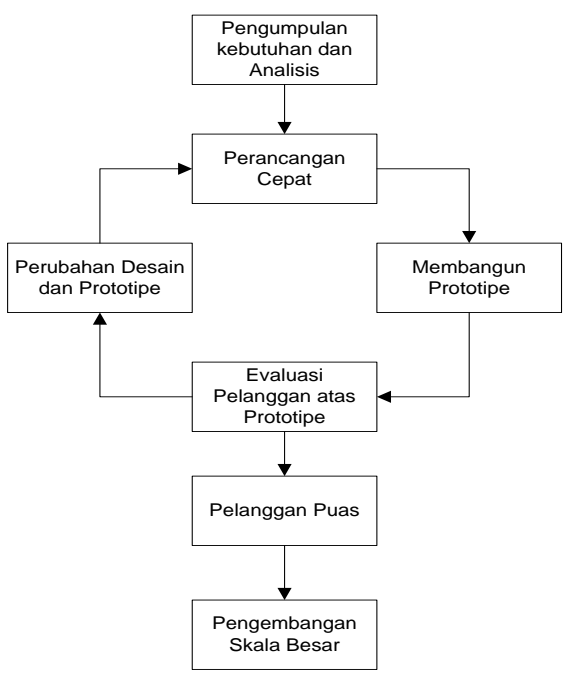


Figure 1

Prototyping

(Source: Simarmata, 2010:63)

\section{Result and Disscussion}

\subsection{Product}

The result of the research is a software application on the admin side which is built using HTML and PHP languages, as well as a MySQL database to form an SMS Gateway system that is used as a medium of information at SMKN 2 Simbang. So with this system, the school can deliver information more easily.

\subsection{Result}

\section{Interface}

Based on the research that has been done, it is obtained an SMS Gateway system as a medium of information at SMKN 2 Sorong Regency which is designed using HTML and PHP languages and MySQL database. The initial activities in making this registration system include planning, then designing the system which is then validated and tested on the research object. The validation and testing phase aims to determine the feasibility and weaknesses of the system before it is implemented

\section{System Validation}

Validation of the SMS Gateway as an information system at SMKN 2 Sorong Regency is a process to assess the feasibility of the product before it will be used as an information system at SMKN 2 Sorong Regency. The tests were carried out by experts who have been given the trust to validate the SMS Gateway system product, namely Dr. Abdul Muis M., S.Pd., M.Pd. M.T with validation result: good.

\section{System Implementation}

The implementation of the system is carried out after the system is validated by experts with results that are in the good category, then the SMS Gateway system is implemented at SMKN 2 Kabupaten Sorong by demonstrating to the admin/school staff to facilitate the process of delivering information. The picture below is a description of the structure of the SMS Gateway program as an information system at SMKN 2 Kabupaten Sorong.

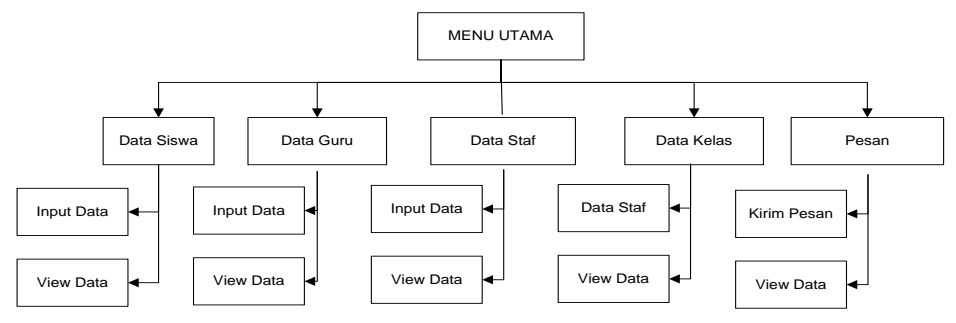

Figure 2

\subsection{Test Result}

SMS Gateway System Structure

\section{a. Black Box Test}

The system test using the black box method shows that the SMS Gateway system as an information system at SMKN 2 Kabupaten Sorong is functioning correctly and as expected. 
Table 1

Black Box Test Result

\begin{tabular}{|c|l|l|c|c|}
\hline No & Test Factor & \multicolumn{1}{|c|}{ Expected Results } & Result & Finding \\
\hline 1 & Admin Login & $\begin{array}{l}\text { Admin can log in to the system } \\
\text { with the correct username and } \\
\text { password }\end{array}$ & OK & Valid \\
\cline { 3 - 5 } & & $\begin{array}{l}\text { Admin cannot log in to the } \\
\text { system with the wrong username } \\
\text { or password }\end{array}$ & OK & Valid \\
\hline 2 & \multirow{2}{*}{ Student Data } & $\begin{array}{l}\text { Admin can add student and } \\
\text { parent/guardians data }\end{array}$ & OK & Valid \\
\cline { 3 - 6 } & $\begin{array}{l}\text { Admin can edit student and } \\
\text { parent/guardians data }\end{array}$ & OK & Valid \\
\hline 4 & Staff Data & Admin can add teacher data & OK & Valid \\
\cline { 3 - 6 } & & Admin can edit teacher data & OK & Valid \\
\hline 5 & Class Data & Admin can add staff data & OK & Valid \\
\cline { 3 - 6 } & Admin can add class data & OK & Valid \\
\hline 6 & Message & $\begin{array}{l}\text { Admin can edit class data } \\
\text { receiver }\end{array}$ & OK & Valid \\
\hline
\end{tabular}

\section{b. Final Product Review}

After validation and testing with a white box and black box method, the explanation below is the final product of the SMS Gateway system as system information at SMKN 2 Kabupaten Sorong.

\section{Interface of Admin Log In}

Before log in to the system, the user must log in as admin by entering the username and password, as illustrated in the picture below.

$$
\begin{aligned}
& \text { Login } \\
& \text { Username } \\
& \text { Password } \\
& \text { Login } \\
& \text { Picture 3 } \\
& \text { Interface of Admin Log-in }
\end{aligned}
$$

After logging in, the admin can add, edit, and sent information to the receiver (student, parent/guardian, teacher, and staff).

\section{Interface of Main System}


The picture 4 below is the main interface of the SMS Gateway system as an information system at SMKN 2 Kabupaten Sorong. The main interface of this system consists of the Student Data menu, Teacher Data, Staff Data, Class Data, and Messages.

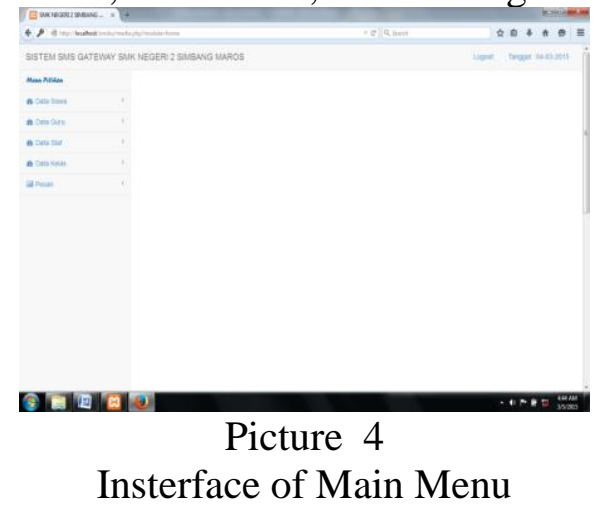

The following is an explanation of each menu on the main menu infterface.

Table 2

Implementation of Menu Structure Interface

\begin{tabular}{ll}
\hline \multicolumn{1}{c}{ Menu } & \multicolumn{1}{c}{ Description } \\
\hline Student Data & $\begin{array}{l}\text { To input student data, and display student data as a } \\
\text { whole or by class. }\end{array}$ \\
Teacher Data & To input teacher data and display teacher data \\
Staff Data & To input staff data and display staff data \\
Class Data & To input class data and display class data \\
Pesan & To send message as an SMS and display message data. \\
\hline
\end{tabular}

\section{Interface of Student Data Menu}

The interface of the student data menu consists of two parts. Data input and data view part.

a. Data Input

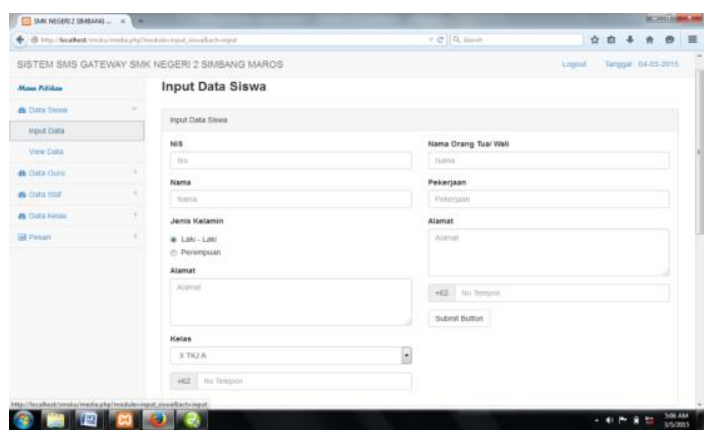

Figure 5

b. Data View

Interface of Student Data Input 


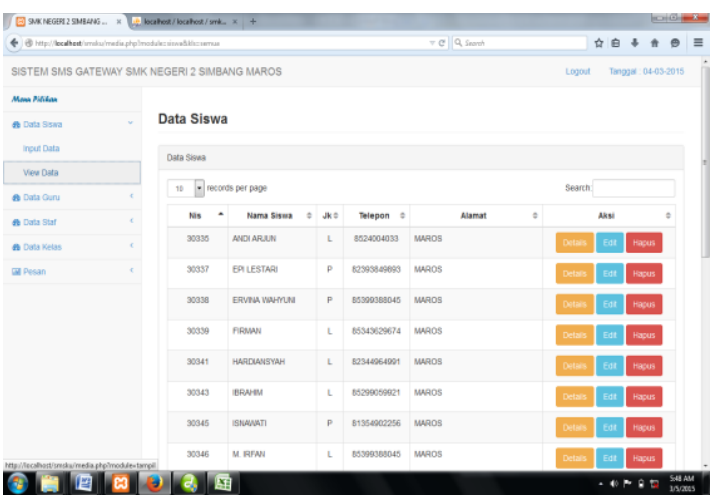

Figure 6

Interface of Student Data View

\section{Interface of Teacher Data Menu}

The interface of teacher data menu consists of two parts. Data input and data view.

a. Interface of Data Input

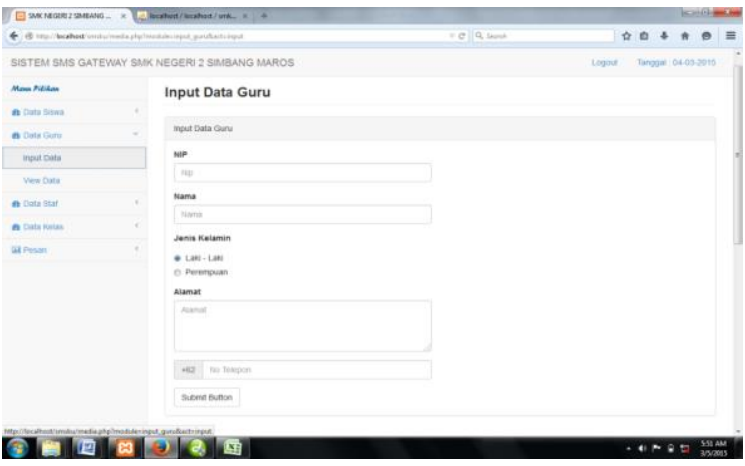

Figure 7

Interface of Teacher Data Input

b. Interface of Data View

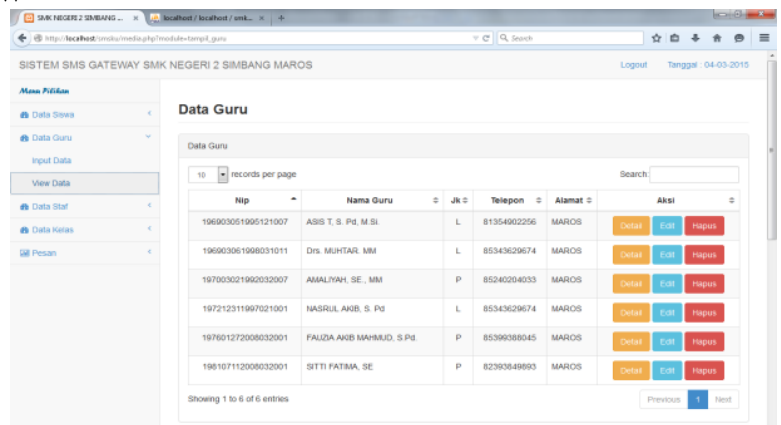

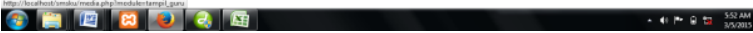

Figure 8

Interface of Teacher Data View

5. Interface of Staff Data Menu

The interface of sraff data menu consists of two parts. Data input and data view.

a. Interface of Data Input 


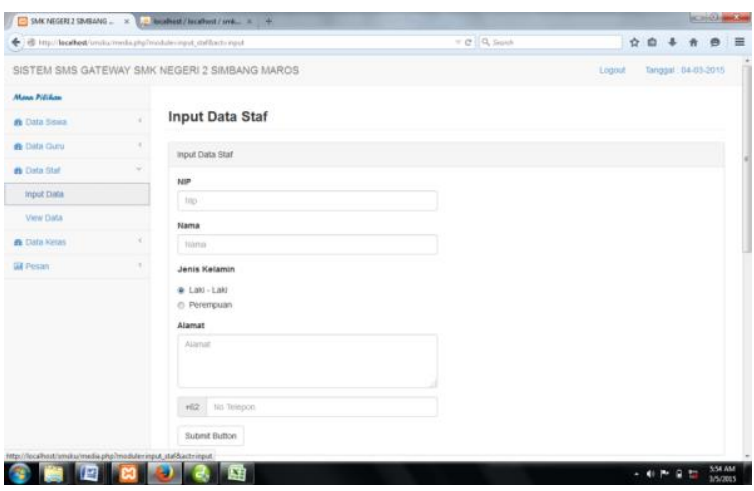

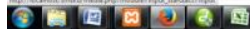

Figure 9

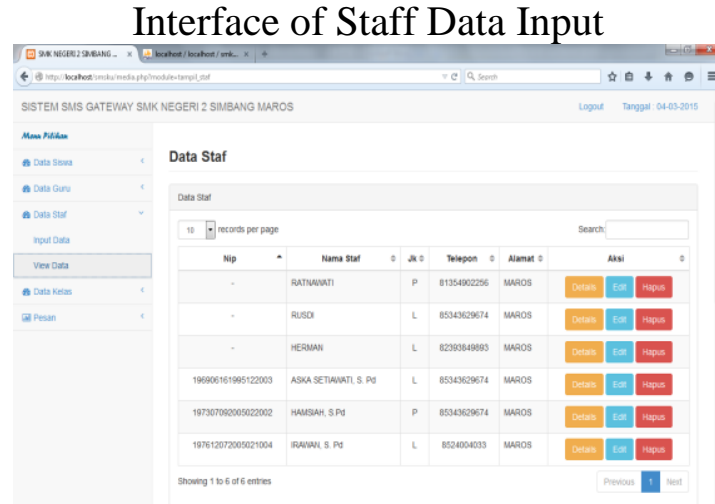

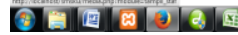

Figure 10

Interface of Staff Data View

\section{Interface of Class Data Menu}

The interface of class data menu consists of two parts. Data input and data view.

a. Interface of data input

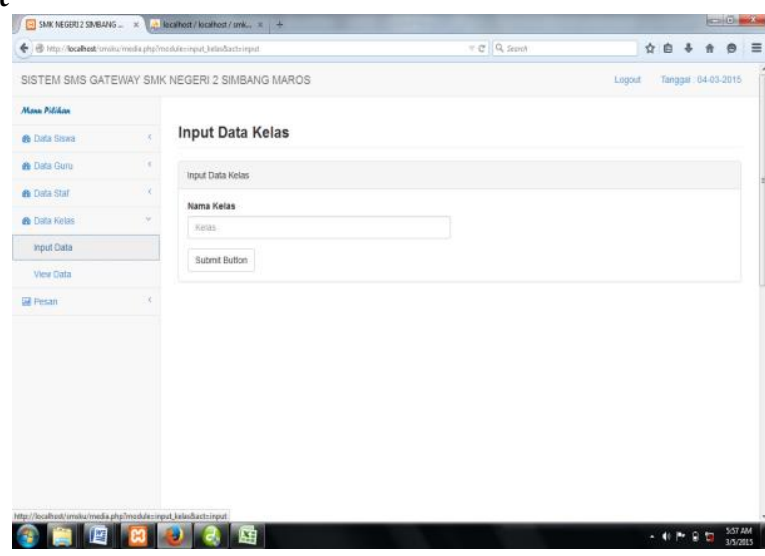

Figure 11

Interface of Class Data Input 


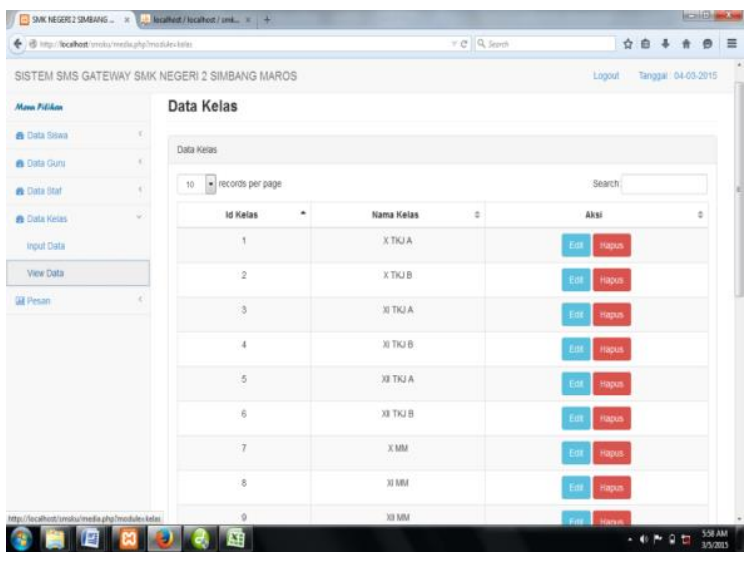

Figure 12

Interface of Class Data View

\section{Interface of Message Menu}

The interface of message menu consists of two parts. Sending message and message data view a. Interface of message menu

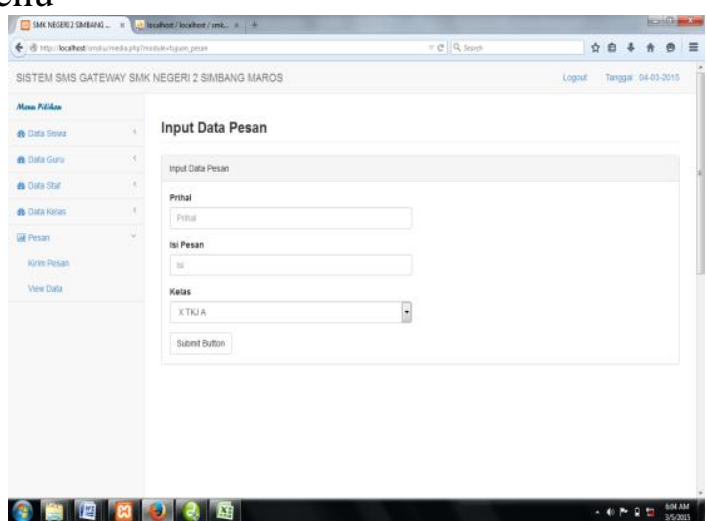

Figure 13

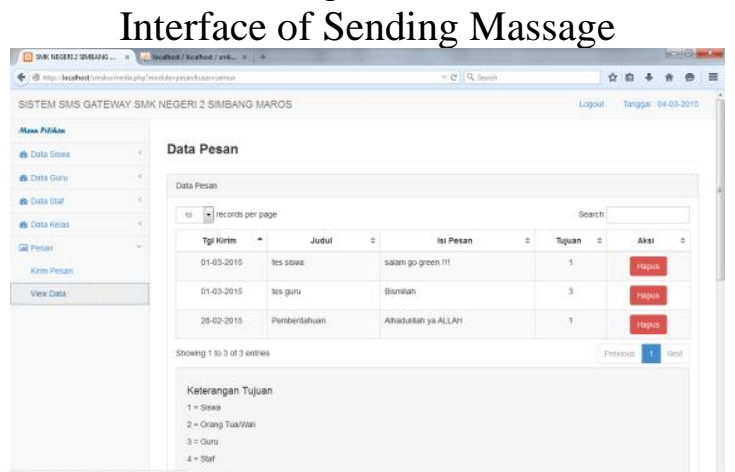

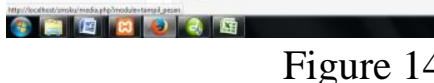

Interface of Message Data View

\section{Conclution}

Based on the results of the study, it can be concluded that the SMS Gateway system being tested at SMKN 2 Kabupaten Sorong can help the school to deliver information to the recipients (students, parents/guardians, teachers, and staff). The SMS Gateway system as an 
information medium that has been designed consists of one level, namely the admin level. Admin must log in first to be able to input data, edit data and send information in the form of SMS messages. Testing the SMS Gateway system as an information system at SMKN 2 Kabupaten Sorong was carried out by black box testing with the result that the functions in the system had functioned correctly as expected.

\section{Reference}

Astuti, Yuli. 2006. Sistem Informasi Akademik Berbasis SMS Gateway pada SMK Batik Perbaik Purworejo. STMIK AMIKOM Yogyakarta. Yogyakarta.

Abidin, R., \& Kuncoro, A. A. (2015). Aplikasi Pembayaran SPP di Lingkungan Yayasan AzZahra Demak Berbasis Client Server Terintegrasi dengan SMS Gateway. JURNAL ELEKTRONIKA DAN KOMPUTER, 8(1).

Fitria, DN. 2010. Sistem Informasi Perpustakaan Online Berbasis PHP dan SMS Gateway di Bangkalan. Politeknik Elektronika Negeri Surabaya Institut Teknologi Sepuluh Nopember (ITS). Surabaya.Suryana, T., \& Indonesia, I. K. U. K. (2012). SMS Gateway Kannel Sebagai Sarana

Khang, Bustam. 2002. Trik Pemrograman Aplikasi Berbasis SMS. Elex Media Komputindo. Jakarta. Penunjang Informasi Akademik. Jurnal Ilmiah Komputer dan Informatika (KOMPUTA), 1(2), 17-30. Sutabri, T. (2012). Analisis sistem informasi. Penerbit Andi.

Novianti dan Fauzijah. 2009. Sistem Informasi Sekolah Dasar Berbasis SMS. Universitas Islam Indonesia. Yogyakarta.

Purwati, Yuli. 2010. Rancang Bangun Aplikasi SMS Gateway sebagai Media Informasi Pembayaran Biaya Kuliah di STMIK AMIKOM Purwokerto. Purwokerto.

\section{Biographies}

Muhammad Ihsan, born in Sinjai, South Sulawesi, November 4, 1993. Completed his Bachelor (S-1) education at FT Univ. Makassar State in 2015, and Master of Education (S-2) at Univ. Makassar State in 2017. After completing his Masters he taught as an Extraordinary Lecturer at the Faculty of Engineering, Makassar State University (2017-2018). In 2018 Worked as a permanent lecturer at the foundation at Univ. Sorong Muhammadiyah Education with Homebase Information Technology Education Study Program. As a permanent lecturer, he has also been given the mandate of being Secretary of LPM (2018-2019), in 2019 he became secretary of the information technology education study program. In the same year, he was given the mandate as chairman of the information technology education study program (2019-2021). During his career several national and international books and articles have been written and published. The article was published in the UNIMUDA Education Journal Sorong and the UNIMUDA Petition Journal Sorong. As a permanent lecturer, he has obtained a functional position as an Expert Assistant.

Leo Pratama was born in Kerinci, December 22, 1993. The fruit of the couple Aswawi Samad and Erwita. since childhood he was introduced to football by his father, several achievements in the sport of football he has achieved starting from the district to provincial levels. Obtained a Bachelor's degree in Sports Education at Jambi University in 2015, then completed a Masters in Sports at Yogyakarta State University in 2018. In early 2019 he began serving as a permanent lecturer at Muhammadiyah Education University Sorong. 2021 is given the trust to be the Chair of the Physical Education Study Program. Apart from being a lecturer, I am also a sports practitioner. Until now, he has published several articles in various national and international articles.

Musyrifah, born November 14, 1993 in Kanang, West Sulawesi. Completed S-1 and S-2 UNM Education Department of Informatics Engineering and Vocational Technology Education. In 2017, he became a speaker at a national seminar with the research title Development of Teaching Factory-based Computer Assembling Learning Models in Vocational High Schools. After graduating from S-2 in 2017, he taught at SMKN 1 Majene. Then in 2018 he was accepted as a permanent lecturer at the University of West Sulawesi in the Informatics Engineering Study Program. During his time as a lecturer, he was active as a member of the MBKM team in the KMMI Digital 
Marketing and Smart Tourism Application Development Kedaireka Program in collaboration with YOY. During his career as a lecturer, he has published several studies. 